\section{BRS Jaspe: a processing peach cultivar for low chill areas}

\section{Maria do Carmo Bassols Raseira ${ }^{1}$, Rodrigo Cezar Franzon ${ }^{1^{*}}$, Nelson Pires Feldberg ${ }^{2}$, Ciro Scaranari ${ }^{3}$ and José Francisco Martins Pereira ${ }^{1}$}

\begin{abstract}
The Embrapa peach breeding program provides a processing peach cultivar, 'BRS Jaspe'. Over the years, the yield of this cultivar was stable and its fruits can be harvested by mid-November and have a good size and taste. It may represent an alternative to cultivar Granada, with a similar maturation period.
\end{abstract}

Keywords: Breeding, Prunus persica, non-melting peach, adaptation to mild winters.

\section{INTRODUCTION}

Peach is one of the most important temperate fruit species worldwide. In 2017, the world production was 24.6 million tons (www.fao.org/faostat/ en/\#data/QC). Aside from the economic importance, peach is socially relevant as well, mainly because of the number of jobs related to the processing industry and consequently impact on the income of numerous families in the region. Peach production in Brazil occupied the $12^{\text {th }}$ position in the world, with a total of $248.583 \mathrm{t}$, produced on an area of 17.118 ha, in 2017 (www.fao.org/faostat/ en/\#data/QC). It is estimated that Southern Rio Grande do Sul (RS) accounts for nearly $35 \%$ of the national peach production. Traditionally, this region produces peach for canneries. Over $90 \%$ of the Brazilian canning industry is located in this region, with an annual production of $40-60$ million cans of peach halves in syrup. The production, of predominantly early-maturing fruits, involves around 1.300 families in the area.

The peach breeding program of Embrapa Clima Temperado (lat $31^{\circ} 40^{\prime} 47^{\prime \prime} \mathrm{S}$, long $52^{\circ} 26^{\prime} 24^{\prime \prime} \mathrm{W}$, alt $60 \mathrm{~m}$ asl), in Pelotas, RS, was initiated at the experimental station of Pelotas, of the Ministry of Agriculture, Livestock and Food Supply (MAPA), as early as in the late 1950's, to develop stone fruits adapted to mild winter conditions (Corrêa et al. 2019). At the beginning of the breeding program, the peach harvest season was concentrated at the end of December and lasted about 15 days. Over the years, the development of new varieties resulted in an extension of this period, mainly by advancing the harvest season (Raseira and Franzon 2014, Raseira et al. 2015). Early-maturing fruits produce higher profits due to their market value (Byrne et al. 2012) at lower production costs. Thus, most fruit growers in this region prefer cultivars that can be harvested before the end of November. This is preferred by the canneries to avoid large amounts of fruits for processing over the Christmas Holidays. The new cultivar BRS Jaspe fulfills this condition.
Crop Breeding and Applied Biotechnology 20(1): e26652015, 2020 Brazilian Society of Plant Breeding. Printed in Brazil http://dx.doi.org/10.1590/198470332020v20n1c5
(1)

.




\section{CULTIVAR CHARACTERISTICS}

\section{Origin}

In 2001, a cross was made between cultivar Ametista and the selection Conserva 594, both of the Embrapa peach breeding program (Figure 2). From the progeny resulting from this cross, plant number 01 was selected in 2005 and given the experimental name Conserva 1578. In the same year, this selection was propagated by grafting and, in 2006, three plants were planted in an experimental collection of Embrapa Temperate Climate. Later, four other plants, also propagated by grafting, were planted in another collection to continue the evaluations. Plants and fruits were assessed annually. In 2015, budded plants of Conserva 1578 were planted in two observations units on properties of peach growers, one in the rural area of Pelotas and the other in Morro Redondo, both in the State of Rio Grande do Sul, where the Embrapa peach breeding program is located.

\section{Plants}

Trees of cultivar BRS Jaspe have medium vigor, a semi-upright growth habit and twigs with short to medium internode length. The flower density is medium to high. Flowers are campanulate (non-showy), with pink roundish petals. Full flowering usually occurs after July $20^{\text {th }}$ and fruit maturation begins in mid-November (Table 1), i.e., together with or very close to that of cultivar Granada and immediately after cultivar BRS Citrino (Raseira et al. 2018). The number of days between full flowering and the first harvest in the evaluated years varied from 89 days (in 2018) to 126 days (in 2011), i.e., the mean harvest period lasts 111 days. This variability is probably due to the wide range of spring temperatures over the years.

The plants of cultivar BRS Jaspe are less susceptible to bacterial leaf spot or fruit brown rot than most peach cultivars.

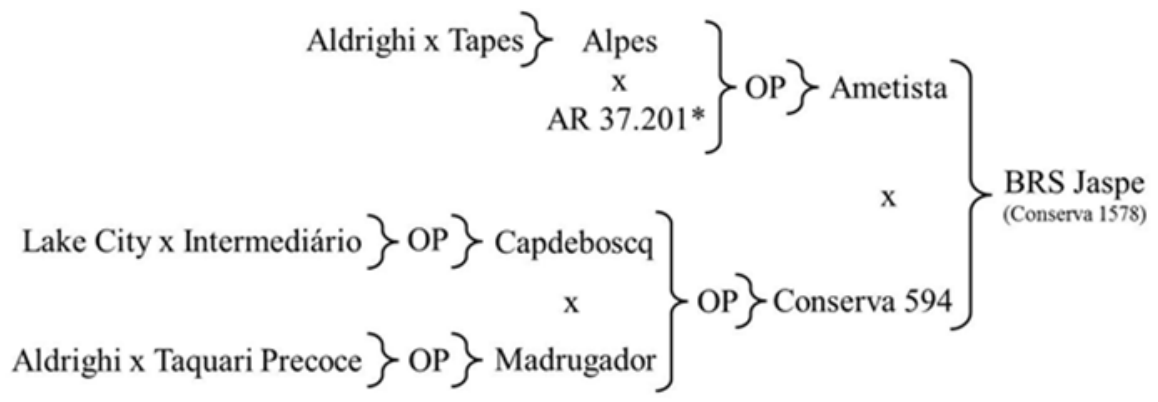

Figure 1. Genealogy of peach cultivar BRS Jaspe. (OP = Open Pollination; *pollen introduced from Rutgers University, New Jersey).
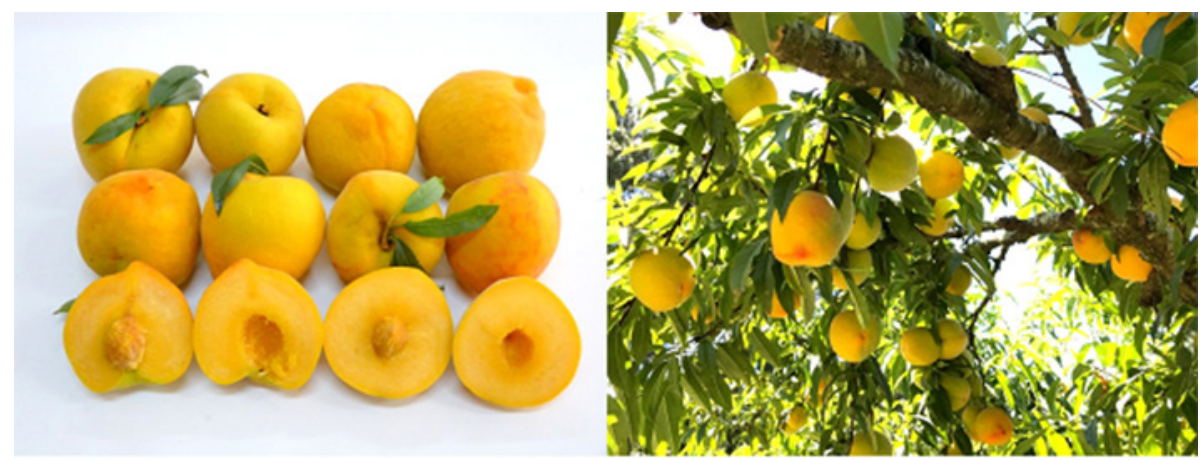

Figure 2. Fruits of 'BRS Jaspe' (Photos: Rodrigo Cezar Franzon). 


\section{Fruits}

Fruits of 'BRS Jaspe' are round, without or with a very small tip, and with a slight suture bulge. They have non-melting, soft, yellow clingstone flesh. The fruits are considered large, usually with a diameter of $>6.2 \mathrm{~cm}$ (type 1 according to local industry criteria, which classifies fruits $>5.7 \mathrm{~cm}$ in this category). In the evaluations in the Embrapa collection, the average fruit diameter varied between 6.0 and $7.3 \mathrm{~cm}$ (Table 2). The mean total soluble solids (TSS) content is between 8.2 and $14.5^{\circ}$ Brix (Table 2), depending on the weather conditions. On a fruit set scale of 1 to 5 , where 3 indicates an acceptable productivity with little or no need for thinning, the fruit set of 'BRS Jaspe' was only below this limit in 2010. Averaged across seven years, this score was 3.6, i.e., higher than that of cultivar Granada with 2. This corresponds to a yield of nearly $20 \mathrm{t} \mathrm{ha}^{-1}$ in an adult orchard, in the region of Pelotas. In other words, the slightly lower mean fruit weight of 'BRS Jaspe' (Table 3 ) is compensated by its consistency of production.

The fruit skin is yellow (Figure 2), with a very slight light red over-color (around 5\%). The taste tends to be balanced between sour and sweet, although in some years a slight bitterness may be detected.

Table 1. Comparison of dates of full flowering and harvest begin of 'BRS Jaspe' and commercial cultivars with similar flowering and harvest periods

\begin{tabular}{|c|c|c|c|c|c|c|c|c|c|c|}
\hline \multirow{2}{*}{ Cultivar } & 2010 & 2011 & 2012 & 2013 & 2014 & 2015 & 2016 & 2017 & 2018 & Mean $^{1}$ \\
\hline & \multicolumn{10}{|c|}{ Full flowering date } \\
\hline BRS Bonão & $7 / 16$ & $7 / 15$ & $7 / 3$ & $*$ & $7 / 10$ & $6 / 28$ & $7 / 09$ & $7 / 15$ & $7 / 27$ & $7 / 11 d$ \\
\hline BRS Citrino & $7 / 17$ & $7 / 21$ & $7 / 19$ & $7 / 11$ & $7 / 16$ & $7 / 24$ & $7 / 08$ & $7 / 19$ & $7 / 31$ & $7 / 18 d$ \\
\hline BRS Jaspe & $8 / 01$ & $7 / 27$ & $7 / 30$ & $7 / 11$ & $*$ & $8 / 01$ & $7 / 18$ & $7 / 19$ & $8 / 04$ & $7 / 25 c$ \\
\hline Granada & $8 / 19$ & $8 / 17$ & $8 / 07$ & $8 / 11$ & $8 / 13$ & $8 / 11$ & $7 / 30$ & $7 / 31$ & $8 / 20$ & $8 / 10 a$ \\
\hline BRS Âmbar & $7 / 22$ & $8 / 08$ & $8 / 06$ & $8 / 05$ & $7 / 25$ & $8 / 06$ & $7 / 20$ & $7 / 23$ & $8 / 12$ & $7 / 31 b$ \\
\hline BRS Bonão & $11 / 10$ & $11 / 16$ & $10 / 30$ & $*$ & $*$ & $10 / 30$ & $10 / 26$ & $10 / 17$ & $*$ & $10 / 31$ e \\
\hline BRS Citrino & $11 / 05$ & $11 / 08$ & $10 / 30$ & $10 / 30$ & $10 / 21$ & $11 / 08$ & $*$ & $*$ & $*$ & $11 / 01 \mathrm{e}$ \\
\hline BRS Jaspe & $11 / 23$ & $11 / 30$ & $11 / 13$ & $11 / 7$ & $*$ & $11 / 12$ & $11 / 16$ & $11 / 08$ & $11 / 01$ & $11 / 13 d$ \\
\hline Granada & $11 / 23$ & $12 / 01$ & $11 / 20$ & $11 / 18$ & $11 / 10$ & $11 / 12$ & $11 / 16$ & $10 / 30$ & $11 / 27$ & $11 / 17 c$ \\
\hline BRS Âmbar & $12 / 06$ & $12 / 09$ & $*$ & $12 / 02$ & $11 / 21$ & $11 / 23$ & $11 / 28$ & $11 / 10$ & $12 / 07$ & $11 / 28 b$ \\
\hline
\end{tabular}

* Missing data. ${ }^{1}$ Dates followed by distinct letters differ statistically by the Scott-Knott test ( $\left.p \leq 0.01\right)$. Statistical analysis of the means was performed using the Rbio software (Bhering 2017). Prior to statistical analysis, the dates were converted to number of days after July $1^{\text {st }}$ for full flowering, and after October $1^{\text {st }}$ for harvest begin. For statistical analysis, the number of days has been transformed to square root.

Table 2. Mean fruit suture diameter $(\mathrm{cm})$ and total soluble solids content ( $\left.{ }^{\circ} \mathrm{Brix}\right)$ of 'BRS Jaspe' and commercial cultivars with similar flowering and harvest periods

\begin{tabular}{|c|c|c|c|c|c|c|c|c|c|c|}
\hline \multirow{2}{*}{ Cultivar } & 2010 & 2011 & 2012 & 2013 & 2014 & 2015 & 2016 & 2017 & 2018 & Mean $^{1}$ \\
\hline & \multicolumn{10}{|c|}{ Fruit diameter $(\mathrm{cm})$} \\
\hline Bonão & 5.8 & $*$ & 6.2 & $*$ & $*$ & 5.5 & 6.1 & 6.6 & $*$ & 6.0 \\
\hline BRS Citrino & $*$ & 6.9 & 5.9 & 6.7 & 6.6 & 6.3 & $*$ & $*$ & $*$ & 6.5 \\
\hline BRS Jaspe & 7.0 & 6.4 & 6.3 & $*$ & $*$ & 6.0 & 6.1 & 6.6 & 7.3 & 6.5 \\
\hline Granada & $*$ & 6.6 & 5.4 & $*$ & 7.5 & $*$ & 6.6 & 7.2 & 7.7 & 6.8 \\
\hline BRS Âmbar & 7.5 & 6.7 & 6.2 & 6.9 & 6.7 & 6.4 & 6.8 & 6.3 & 6.7 & 6.7 \\
\hline Bonão & 15.4 & $*$ & 8.8 & $*$ & $*$ & 8.5 & 7.1 & 9.8 & $*$ & $9.9 \mathrm{~b}$ \\
\hline BRS Citrino & $*$ & 11.2 & 8.7 & 7.4 & 7.9 & 8.2 & $*$ & $*$ & $*$ & $8.7 \mathrm{~b}$ \\
\hline BRS Jaspe & 11.9 & 11.1 & 11.4 & $*$ & $*$ & 9.0 & 9.1 & 8.2 & 14.5 & $10.7 \mathrm{~b}$ \\
\hline Granada & $*$ & 9.8 & 10.1 & $*$ & 9.7 & 9.6 & 9.5 & 11.7 & 12.1 & $10.4 \mathrm{~b}$ \\
\hline BRS Âmbar & 14.7 & 11.5 & 12.7 & 11.3 & 12.6 & 7.9 & 11.3 & 10.2 & 13.3 & $11.7 \mathrm{a}$ \\
\hline
\end{tabular}

* Missing data. ${ }^{1}$ Means followed by distinct letters differ statistically by the Scott-Knott test $(p \leq 0.01)$. Statistical analysis of the means was performed using the Rbio software (Bhering 2017). 
Table 3. Fruit set and mean fruit weight $(\mathrm{g})$ of 'BRS Jaspe' and commercial cultivars with similar flowering and harvest periods

\begin{tabular}{|c|c|c|c|c|c|c|c|c|c|c|}
\hline \multirow{2}{*}{ Cultivar } & 2010 & 2011 & 2012 & 2013 & 2014 & 2015 & 2016 & 2017 & 2018 & Mean $^{2}$ \\
\hline & \multicolumn{10}{|c|}{ Fruit set $^{1}$} \\
\hline Bonão & 3 & 4 & 5 & 2 & 1 & 0.5 & 1 & 1 & * & $2.2 \mathrm{~b}$ \\
\hline BRS Citrino & 4 & 4.5 & 5 & 5 & 2 & 4 & 3.5 & 1 & * & $3.6 \mathrm{a}$ \\
\hline BRS Jaspe & 2 & 5 & 4 & 3 & $*$ & 3 & 4 & 4 & 4 & $3.6 \mathrm{a}$ \\
\hline Granada & 4 & 2 & 2 & $*$ & $*$ & $*$ & 2 & 1 & 1 & $2.0 \mathrm{~b}$ \\
\hline BRS Âmbar & 2 & 4 & 5 & 4 & 2 & 4 & 4 & 2.5 & $*$ & $3.4 \mathrm{a}$ \\
\hline Bonão & 87 & 119 & 92 & $*$ & $*$ & 90 & 110 & 132 & $*$ & $105 \mathrm{~b}$ \\
\hline BRS Citrino & 118 & 115 & 100 & 126 & 130 & 116 & $*$ & $*$ & * & $118 \mathrm{~b}$ \\
\hline BRS Jaspe & 128 & 115 & 130 & 189 & $*$ & 117 & 110 & 122 & 144 & $132 b$ \\
\hline Granada & 84 & 145 & 100 & 160 & 185 & 190 & 215 & 206 & 217 & $167 a$ \\
\hline BRS Âmbar & 200 & 185 & 110 & 200 & 135 & 125 & 170 & 132 & 149 & $156 \mathrm{a}$ \\
\hline
\end{tabular}

${ }^{1}$ Fruit set rated on a $1-5$ scale, where 1 = very few fruits; 2 = low fruit set; 3 = commercially acceptable fruit set, without need for thinning; 4 = high fruit set requiring thinning; and $5=$ excessive fruit set. * Missing data of trees used for crosses in the breeding program. ${ }^{2}$ Means followed by distinct letters differ statistically by the Scott-Knott test $(p \leq 0.01)$. Statistical analysis of the means was performed using the Rbio software (Bhering 2017), and the fruit set data has been transformed by the equation log $(x)$.

The final product of cultivar BRS Jaspe, i.e., peach halves in syrup (Figure 3), was considered superior to the product found on the market.

\section{Adaptation}

The estimated chilling requirement of this cultivar is 200 to 300 hours $\left(\leq 7.2^{\circ} \mathrm{C}\right)$.

\section{Availability}

Budwood or plants of cultivar BRS Jaspe can be obtained at licensed nurseries, listed at: <https://www.embrapa. br/cultivares>.

\section{REFERENCES}

Bhering LL (2017) Rbio: A tool for biometric and statistical analysis using the R platform. Crop Breeding and Applied Biotechnology 17: $187-190$.

Byrne DH, Raseira MCB, Bassi B, Piagnani MC, Gasic K, Reighard GL, Moreno MA and Perez S (2012) Peach. In Badenes ML and Byrne D (eds). Fruit breeding. Springer Science Business Media, Philadelphia, p. 505-565.

Corrêa ER, Nardino M, Barros WS and Raseira MCB (2019) Genetic progress of the peach breeding program of Embrapa over 16 years. Crop Breeding and Applied Biotechnology 19: 319-328.

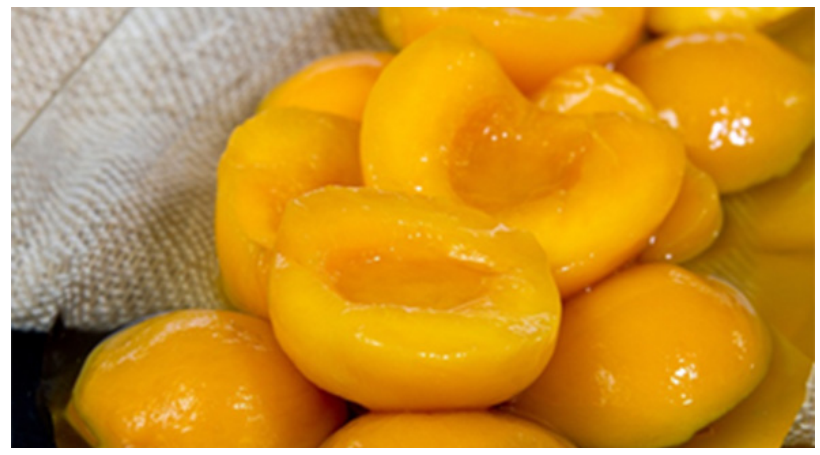

Figure 3. Peach halves in syrup, of cultivar BRS Jaspe (Photo: Paulo Lanzetta).

Raseira MCB, Franzon RC, Pereira JFM, Scaranari C and Feldberg NP (2018) Peach cultivar BRS Citrino. Crop Breeding and Applied Biotechnology 18: 234-236.

Raseira MCB, Franzon RC, Scaranari C, Feldberg NP and Pereira JFM (2015) Programa de melhoramento genético de frutas de caroço da Embrapa. In Belarmino LC, Franzon RC, Pereira JFM, Raseira MCB and Nava G (eds). Anais do 60 encuentro latinoamericano prunus sin fronteras. Embrapa, Brasília, p. 74-76.

Raseira MCB and Franzon RC (2014) Melhoramento genético. In Raseira MCB, Pereira JFM and Carvalho FLC (eds). Pessegueiro. Embrapa, Brasília, p. 57-72. 